Egyptian Journal of Aquatic Biology \& Fisheries

Zoology Department, Faculty of Science,

Ain Shams University, Cairo, Egypt.

ISSN $1110-6131$

Vol. 24(7): 1097 - 1114 (2020)

www.ejabf.journals.ekb.eg

\title{
List of phytoplankton species of the northeastern part of Lake Manzala, Egypt
}

\author{
Hany T. Yassin ${ }^{1}$, Fedekar F. Madkour ${ }^{2, *}$, Mohamed A. Deyab ${ }^{1}$ and \\ Seham E. Abu Ahmed ${ }^{1}$ \\ 1- Department of Botany and Microbiology, Faculty of Science, Damietta University, New \\ Damietta City, 34517, Egypt \\ 2- Department of Marine Science, Faculty of Science, Port Said University, Port Said, Egypt \\ "Corresponding Author: fedekarmadkour@ymail.com
}

\section{ARTICLE INFO}

Article History:

Received: Dec. 26, 2020

Accepted: Dec. 28, 2020

Online:Dec. 31, 2020

Keywords:

Lake Manzala,

phytoplankton

composition,

Ashtoum El-Gamil

Protectorate,

species diversity.

\begin{abstract}
The present study was conducted in Lake Manzala at Ashtoum El-Gamil Protected Area that locates in the northeastern part of the lake. Subsurface water samples for phytoplankton investigation were collected monthly from four sites during October 2013-September 2014. A list of 109 species was identified and classified into a specific level. The recorded species belonged to 59 genera and was classified into seven Phyla. Bacillariophyta was the most diversified group with the highest number of the recorded species (51 species, 26 genera), constituting $47 \%$ of the phytoplankton community. The three Phyla; Chlorophyta, Dinoflagellata, and Cyanobacteria contained a relatively close number of species (17, 16 and 13 species, respectively) and occupied the second order, collectively belong to 27 genera, constituting $43 \%$ of the phytoplankton community. The other three Phyla; Euglenozoa, Charophyta, and Ochrophyta (Dictyochophyceae) were represented by a low number of species $(5,5$, and 2 species, respectively forming 10\%), and each belongs to two genera. The composition of the phytoplankton community in Lake Manzala was greatly influenced by the relatively high inflows of both freshwater and nutrients into the lake, producing a phytoplankton community dominated by Chlorophyta, and Cyanophyta which had fresh and brackish water affinity. In addition, receiving seasonal backflows of seawater from the Mediterranean Sea and Suez Canal enhanced the Bacillariophyta and Dinoflagelata species.
\end{abstract}

\section{INTRODUCTION}

Lake Manzala is the largest and most productive brackish coastal lakes fringing the Nile Delta of Egypt. It is located in the north-eastern extremity of the Nile Delta at latitudes $31^{\circ} 07^{\prime} \mathrm{N}$ and $31^{\circ} 30^{\prime} \mathrm{N}$, and longitudes $31^{\circ} 48^{\prime} \mathrm{E}$ and $32^{\circ} 17^{\prime} \mathrm{E}$ (Elmorsi et al., 2017). Its northern border is a narrow sandy beach, which separates the lake from the Mediterranean Sea. It is bounded by Suez Canal at the east, Damietta branch of the Nile to the west, Dakahliya province in the southwest and Sharkiya Governorate in the southeast (El-Sherif and Gharib, 2001). Although the lake is still considered as the 
largest of the Egyptian Delta lakes, its area has been gradually decreased since the early decades of the last century. In 1900's its area was estimated at about 1,709 $\mathrm{km}^{2}$ (Fouad, 1926). The gross area of the lake was progressively reduced as estimated by satellite images during 1973 - 2013 from 1,100 km² in 1973 to $385 \mathrm{~km}^{2}$ in 2013 (Hereher, 2014; El-Asmar and Hereher, 2015). This shrinking in the lake area was attributed to the continuous processes of agricultural land, reclamation activities and to the construction of the coastal highway. The lake is shallow with a depth range of $0.6-1.5 \mathrm{~m}$, and $35 \mathrm{~km}$ length from northwest to southeast and $30 \mathrm{~km}$ width (Abdel- Moati, 1985; Fayed, 2004; Rashad and Abdel-Azeem, 2010).

At the north border, Lake Manzala is connected to the Mediterranean Sea by five openings; they are from the east to west: old Ashtoum El-Gamil, new Ashtoum Al-Gamil, Al-Baghdadi, El-Deiba and Al-Burg . Near the northeast part, the lake is connected with the Suez Canal through a small canal (Al-Qabouti Canal). These six outlets supply the lake with marine water. The western and southern borders have many inlets that introduce great amount of wastewater discharges into the lake. The most important drainage are Bahr El-Baqar, Bahr Hadous, Ramsis, Al-Sirw, Abu Garida and Faraskur drains. The northwestern part of the lake is connected to Damietta estuary via the two canals El-Ratama and El-Souffara. These canals were constructed mainly to freshen the north-western part of the lake by Nile water during the flood season (El-Bokhty, 1996; Aamer, 1999).

Ashtoum El-Gamil Protected Area was declared as a nature protectorate according to the Prime ministerial decree No. 459 for 1988. It locates in the eastern north corner of Lake Manzala, including old and new Ashtoum El-Gamil inlets $\left(31^{\circ} 15^{\prime} \mathrm{N}, 32^{\circ} 10^{\prime} \mathrm{E}\right)$. The main purpose for creating this protected area was the protection of many resident and migratory species of birds, marine and fresh water fish, natural plants and historical sites scattered throughout the lagoon. It represents a modest example of a highly threatened and rapidly disappearing habitat in Egypt and the Mediterranean basin (Ibrahim, 1989; Meininger and Atta, 1992).

Phytoplankton constitutes the primary producers that able to absorb and assimilate nutrients in aquatic environments and comprise the base of the food chain (Smolyakov $\boldsymbol{e t}$ al., 2010). Thus, the diversity and abundance of phytoplankton in aquatic ecosystems reflect the ecological condition and, therefore, can used as a bioindicators of aquatic pollution and ecosystem health (Abd El-Monem and Kanswa, 2001; Madkour et al., 2007a). Lake Manzala are heavily impacted by human activities and suffers from exposure to high inputs of industrial, domestic, and agricultural pollutants that can degrade water quality causing eutrophication and alter phytoplankton community (Delgado, 1990; Ismail and Hettiarachchi, 2017). A number of studies have been conducted on the phytoplankton species composition and abundance of Lake Manzala (Khalil, 1990; Gab-Allah, 1990; El-Naggar et al., 1997; El-Sherif and Gharib, 2001; 
Fathi et al., 2001, Salah El Din, 2005; Madkour, 2007a; Abd El-Karim, 2008; Ramdani et al., 2009; Deyab et al., 2019). However, the continuous change in the lake morphology and adding sources of industrial wastes has direct impact on its water quality and biodiversity, making the continuous monitoring of water quality is mandatory. The aim of the present research is to compile a taxonomically sound checklist of phytoplankton and to study the spatio-temporal variation in the species composition of phytoplankton in the north eastern part of Lake Manzala.

\section{MATERIALS AND METHODS}

\section{Study area}

The present study was conducted at Ashtoum El-Gamil Protected Area in Lake Manzala locates between Bahr El-Bashtier in the south and Ashtoum El-Gamil in the north. This area covers the part of the lake which is affected by sewage, agricultural and industrial wastes. Four sites were chosen to cover the different types of pollutants that affect the water quality and the phytoplankton growth in Lake Manzala. Site I locates at Bahr Al Kur in El-Gamil area and receives sewage and industrial wastes. Site II lies in front of New Boughaz El-Gamil (seawater exchange). Site III locates at Bahr El-Bashtier (industrial, agriculture and sewage wastes). Site IV lies at Al-Raswa in El-Qabouti Canal (sewage and industrial wastes) (Fig. 1). The coordinates of selected sites are represented in Table (1).

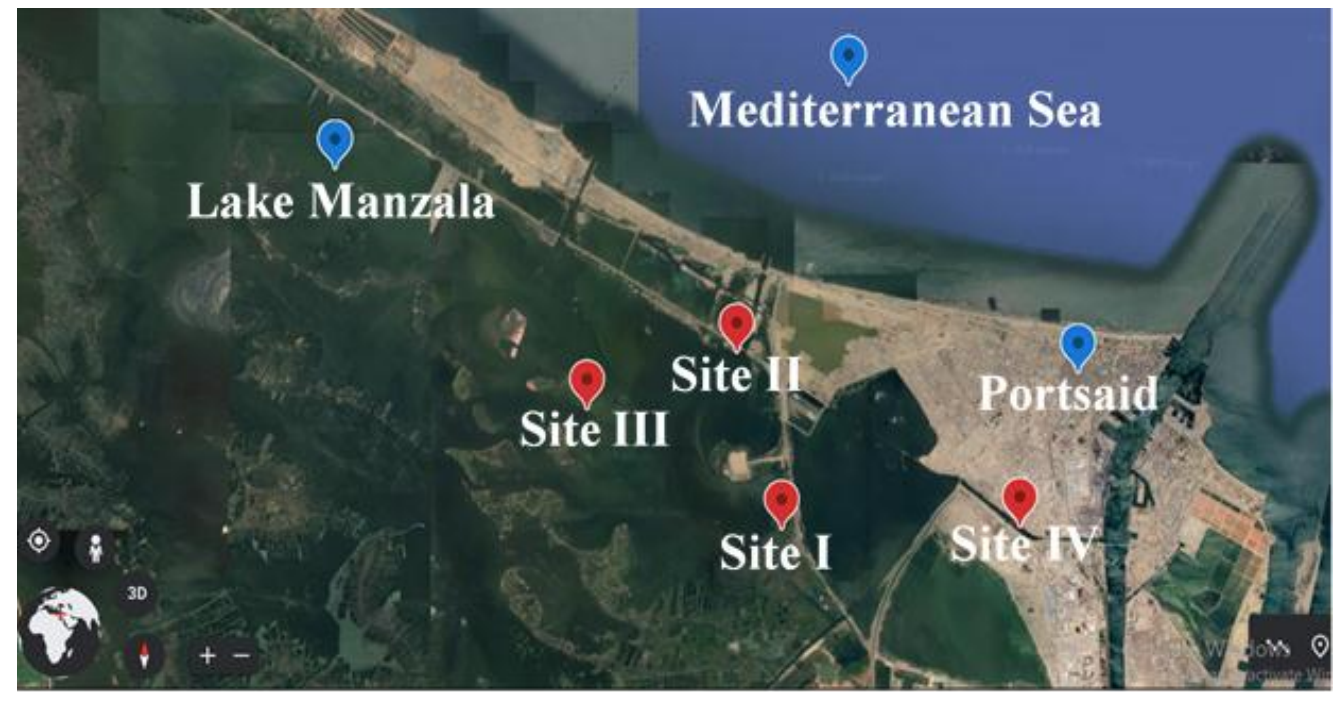

Fig. 1. Location of the studied sites in Lake Manzala. 
Table 1. Coordinates of studied sites in the northeastern Lake Manzala.

\begin{tabular}{c|l|c|c}
\hline Site & \multicolumn{1}{|c|}{ Location } & Longitude & Latitude \\
\hline I & Bahr Al Kur at Al Gamil area & $31^{\circ} 13^{\prime} 44^{\prime \prime} \mathrm{N}$ & $32^{\circ} 13^{\prime} 21^{\prime \prime} \mathrm{E}$ \\
II & Boughaz El-Gamil & $31^{\circ} 16^{\prime} 04^{\prime \prime} \mathrm{N}$ & $32^{\circ} 12^{\prime} 34^{\prime \prime} \mathrm{E}$ \\
III & Bahr El-Bashtier & $31^{\circ} 15^{\prime} 07^{\prime \prime} \mathrm{N}$ & $32^{\circ} 10^{\prime} 19^{\prime \prime} \mathrm{E}$ \\
IV & Al Raswa & $31^{\circ} 14^{\prime} 08^{\prime \prime} \mathrm{N}$ & $32^{\circ} 16^{\prime} 49^{\prime \prime} \mathrm{E}$ \\
\hline
\end{tabular}

\section{Phytoplankton sampling and identification}

Subsurface water samples (2 liters) for phytoplankton investigation were collected monthly from October 2013 to September 2014. For preservation, each sample was divided into two parts (1 liter each), one of them was preserved with Lugol's solution and the other with $4 \%$ neutral formalin. Each sample was then allowed to settle for two days and then the supernatant was siphoned off slowly and the volume was adjusted to $100 \mathrm{ml}$ and kept in dark bottles until analysis. Phytoplankton species were investigated using inverted microscope (OPTIKA), and algal taxa were identified according to the standard references, including Hendey (1964), Riley (1967), Prescott (1978), Bourrelly (1980) and Botes (2003).

\section{Statistical analysis}

Differences between sites and months were tested by one way analysis of variance (ANOVA) using software program SPSS V. 17 with significant level at 0.05 .

\section{RESULTS}

\section{Phytoplankton species composition}

In the present study, phytoplankton was collected for a year during October 2013September 2014 at four sites from Ashtoum El-Gamil Protectorate in Lake Manzala. A total of 109 species belong to 59 genera was recorded and classified into seven Phyla. Bacillariophyta was the most diversified group with the highest number of the recorded species (51 species) belongs to 26 genera, constituting 47\% of the phytoplankton community (Fig. 2). The three Phyla; Chlorophyta, Dinoflagellata and Cyanobacteria contained relatively close number of species (17, 16 and 13 species, respectively) and occupied the second order, collectively belong to 27 genera constituting $43 \%$ of the phytoplankton community. The other three Phyla; Euglenozoa, Charophyta and Ochrophyta (Dictyochophyceae) were represented by a very low number of species $(5,5$ and 2 species, respectively forming 10\%), and each belong to two genera (Fig. 2). The dominant genera, in terms of the number of species, were Navicula, Nitzschia, Prorocentrum (6 species each) and Scenedesmus (5 species). 


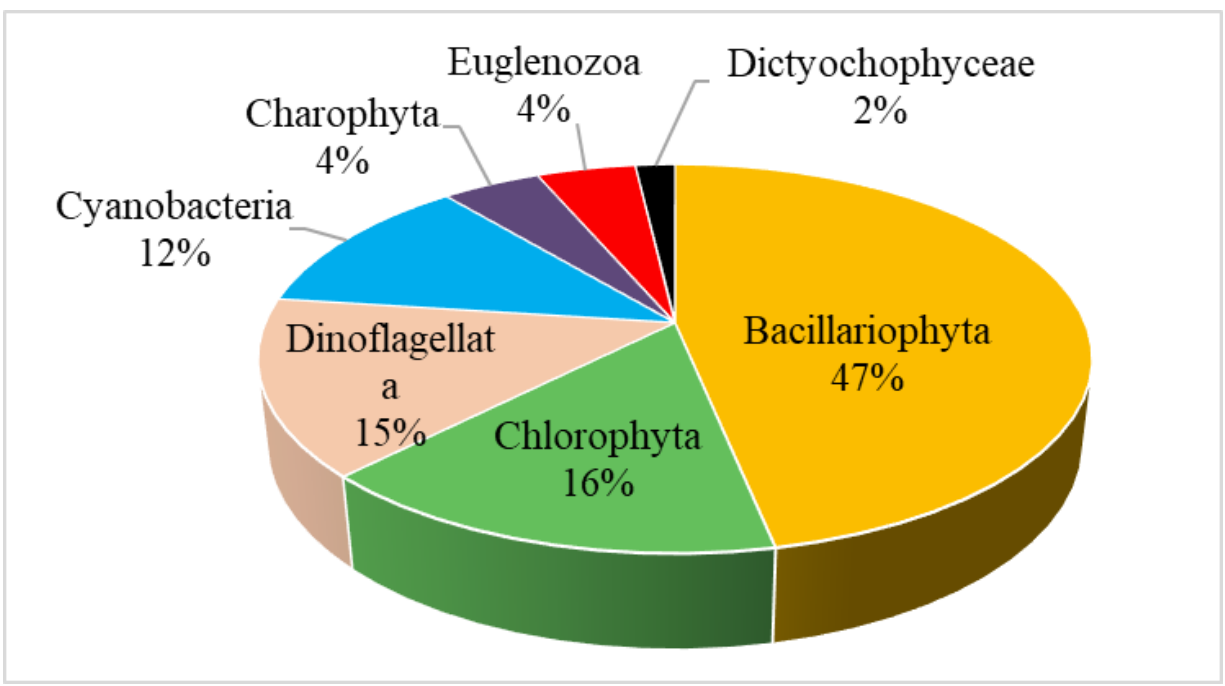

Fig. 2. The percentage of species number of each recorded phytoplankton group in Lake Manzala during October 2013-September 2014.

\section{Spatio-temporal variation of phytoplankton species number}

The total number of phytoplankton species recorded at each site in Lake Manzala varied monthly during study period (Fig. 3). Site I showed the highest number of species most of the year (range: 32-62 species in October and June, respectively), with significant monthly variation (ANOVA, p 0.05 ). Sites IV and III alternate the situation in terms of species number where site IV harboured more species during the period July-November, and site III harboured more species during the period January to June, with the same range of species number (34-55 species) and non significant monthly variation (ANOVA, $\mathrm{p}>0.05$ ) for both sites. On the other hand, site II demonstrated the lowest number of species throughout the whole period of study (range: 27-51 species), with significant monthly variation (ANOVA, $\mathrm{p}<0.05$ ).

The monthly average frequency of the all phytoplankton species in the whole study area showed high values during spring and summer seasons (March-August) with the maximum value (55 species) in June, while low values were observed during autumn and winter seasons (September-February) with the minimum value (37 species) in October (Fig. 4). During the entire study period, Bacillariophyta displayed the highest frequency (range: 15-28 species in October and June, respectively), followed by Chlorophyta which scored the second order in frequency, ranging between 7 species in January and February and 12 species in June. Cyanobacteria and Dinoflagellata came in the third and fourth orders, respectively and their frequency did not exceed 7 species throughout the whole study period. The remaining groups of phytoplankton showed lower frequency, collectively ranged between 2-5 species (Fig. 4). 


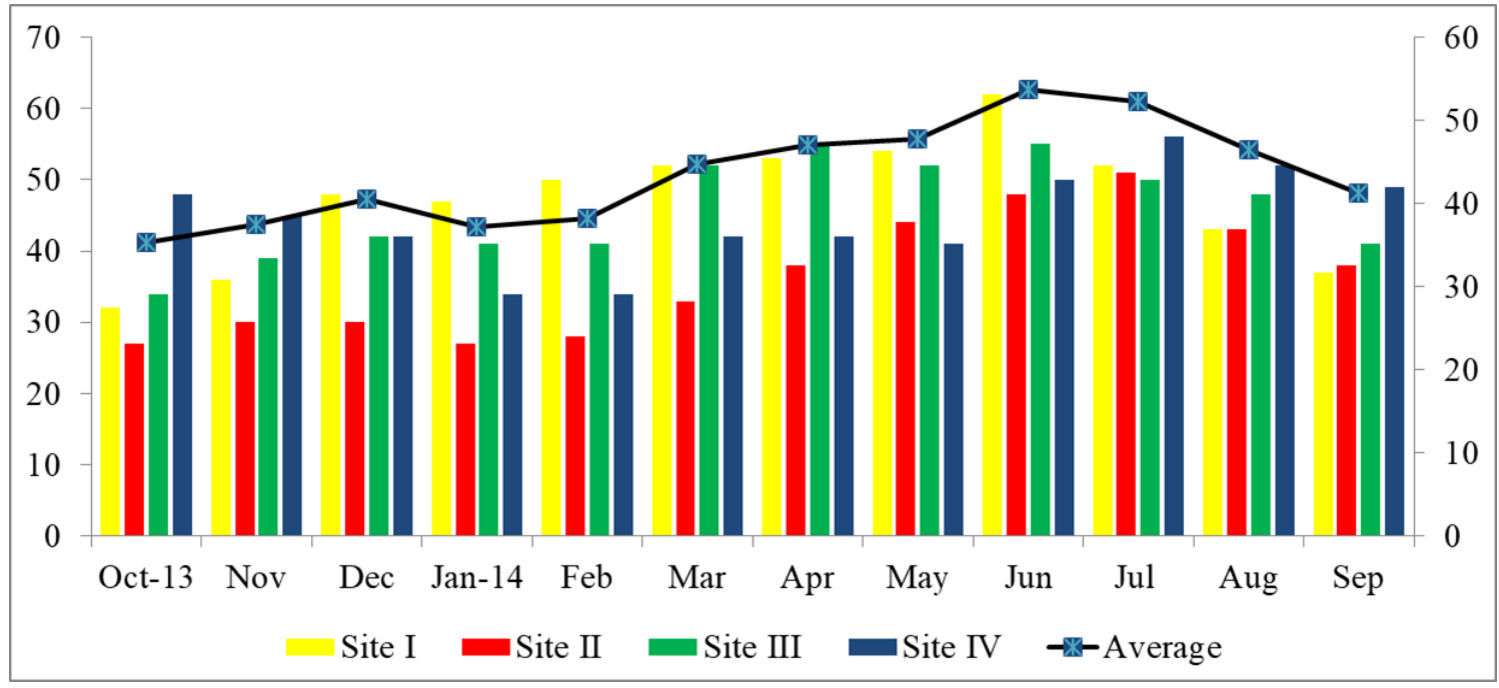

Fig. 3. Monthly variation of total phytoplankton species number at each site in Lake Manzala during October 2013 to September 2014.

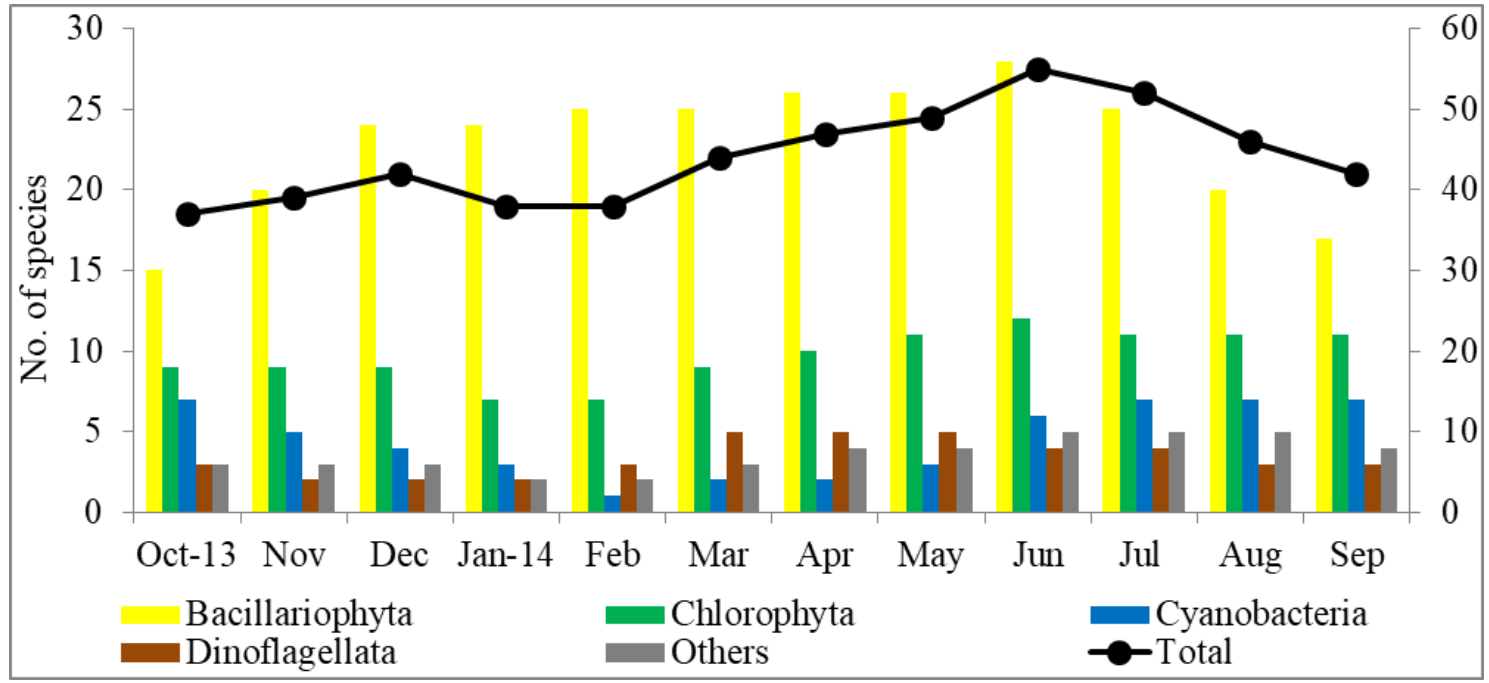

Fig. 4. Monthly average of the species number of phytoplankton groups in Lake Manzala during October 2013 to September 2014.

The annual average of species number of phytoplankton groups at each site during the whole study period illustrated little variation with non-significant difference (ANOVA, p>0.05). Bacillariophyta showed the highest frequency (range: 19-27 species at sites II and III, respectively), followed by Chlorophyta (range: 7-12 species at sites II and III, respectively) (Fig. 5). Cyanobacteria and Dinoflagellata ranged between 2-5 species while other groups did not exceed 2 species. 


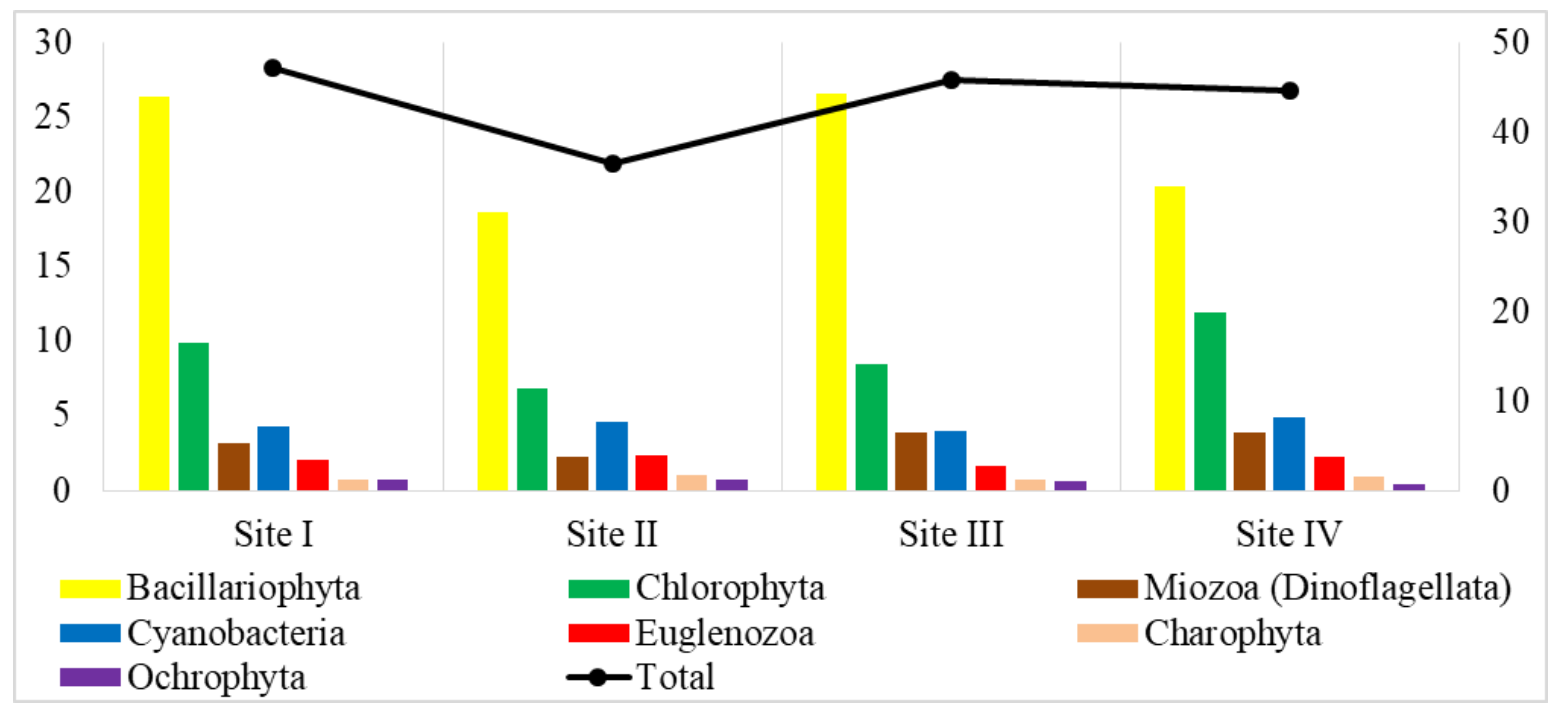

Fig. 5. The number of species of phytoplankton groups at each site in Lake Manzala during October 2013 to September 2014.

The list of the recorded phytoplankton species in Lake Manzala during October 2013 to September 2014 with their systematic position are given. The accepted names and valid taxonomy of the phytoplankton species are based on the taxonomic database online sites such as AlgaeBase.com (AB) and World Register of Marine Species (WoRMS).

Empire: Prokaryota Allsopp

Kingdom: Eubacteria Cavalier-Smith

Phylum: Cyanobacteria Stanier ex Cavalier-Smith

Class: Cyanophyceae Schaffner

Subclass: Nostocophycidae Hoffmann, Komárek \& Kastovsky

Order: Nostocales Borzì

Family: Nostocaceae Eichler

Genus: Anabaena Bory ex Bornet \& Flahault

A. azollae Strasburger

Genus: Nostoc Vaucher ex Bornet \& Flahault

$N$. commune Vaucher ex Bornet \& Flahault

Subclass: Oscillatoriophycidae L.Hoffmann, J.Komárek \& J.Kastovsky

Order: Chroococcales Schaffner

Family: Microcystaceae Elenkin

Genus: Gloeocapsa Kützing

G. magma (Brébisson) Kützing

Genus: Microcystis Lemmermann

M. aeruginosa (Kützing) Kützing

Family: Chroococcaceae Rabenhorst

Genus: Chroococcus Nägeli

C. disperses (Keissler) Lemmermann 


\section{C. minor (Kützing) Nägeli}

Order: Oscillatoriales Schaffner

Family: Oscillatoriaceae Engler

Genus: Oscillatoria Vaucher ex Gomont

O. rubescens De Candolle ex Gomont

O. tenuis C.Agardh ex Gomont

Order: Spirulinales J.Komárek, J.Kastovsky, J.Mares \& J.R.Johansen

Family: Spirulinaceae (Gomont) L.Hoffmann, J.Komárek \& J.Ka

Genus: Spirulina Turpin ex Gomont

S. platensis (Gomont) Geitler

S. subsalsa Oersted ex Gomont

Subclass: Synechococcophycidae L.Hoffmann, J.Komárek \& J.Kastovsky

Order: Synechococcales L.Hoffmann, J.Komárek \& J.Kastovsky

Family: Merismopediaceae Elenkin

Genus: Merismopedia Meyen

M. elegans Braun ex Kützing

$M$. punctata Meyen

M. tenuissima Lemmermann

Empire: Eukaryota Chatton

Kingdom: Chromista Cavalier-Smith

Phylum: Bacillariophyta Karsten

Class: Bacillariophyceae Haeckel

Subclass: Bacillariophycidae D.G.Mann

Order: Thalassiophysales D.G.Mann

Family: Catenulaceae Mereschkowsky

Genus: Amphora Ehrenberg ex Kützing

A. ovalis (Kützing) Kützing

Order: Cocconeidales E.J.Cox

Family: Cocconeidaceae Kützing

Genus: Cocconeis Ehrenberg

C. pediculus Ehrenberg

C. placentula Ehrenberg

C. scutellum Ehrenberg

Order: Cymbellales D.G.Mann

Family: Cymbellaceae Kützing

Genus: Cymbella C.Agardh

C. delicatula Kützing

Order: Naviculales Bessey

Family: Naviculaceae Kützing

Genus: Gyrosigma Hassall

G. acuminatum (Kützing) Rabenhorst

Genus: Navicula Bory

$N$. angusta Grunow

$N$. cancellata Donkin

N. cuspidate (Kutzing) Kutzing

N. gastrum (Ehrenberg) Kützing 
$N$. lanceolata Ehrenberg

$N$. palpebralis Brébisson ex W.Smith

Genus: Trachyneis P.T.Cleve

T. aspera (Ehrenberg) Cleve

Family: Stauroneidaceae D.G.Mann

Genus: Fistulifera Lange-Bertalot

$F$. pelliculosa (Kützing) Lange-Bertalot

Family: Pleurosigmataceae Mereschowsky

Genus: Pleurosigma W.Smith

$P$. capense Petit

Family: Pinnulariaceae D.G.Mann

Genus: Pinnularia Ehrenberg

P. major (Kützing) Rabenhorst

$P$. variarea Metzeltin \& Krammer

$P$. viridis (Nitzsch) Ehrenberg

Order: Lyrellales D.G.Mann

Family: Lyrellaceae D.G.Mann

Genus: Petroneis A.J.Stickle \& D.G.Mann

P. monilifera (Cleve) Stickle \& D.G.Mann

Order: Mastogloiales D.G.Mann

Family: Mastogloiaceae Mereschkowsky

Genus: Decussiphycus Guiry \& Gandhi

D. placenta (Ehrenberg) Guiry \& Gandhi

Order: Bacillariales Hendey

Family: Bacillariaceae Ehrenberg

Genus: Cylindrotheca Rabenhorst

C. closterium (Ehrenberg) Reimann \& J.C.Lewin

Genus: Nitzschia Hassall

$N$. angularis W.Smith

N. australis (Peragallo) A.Mann

N. longissima (Brébisson) Ralfs

$N$. palea (Kützing) W.Smith

$N$. regula Hustedt

$N$. sigma (Kützing) W.Smith

Genus: Pseudonitzschia H.Peragallo

$P$. australis Frenguelli

P. delicatissima (Cleve) Heiden

Subclass: Fragilariophycidae Round

Order: Tabellariales Round

Family: Tabellariaceae Kützing

Genus: Asterionella Hassall

A. formosa Hassall

Genus: Diatoma Bory

D. elongate (Lyngbye) C.Agardh

D. mesodon (Ehrenberg) Kützing

D. vulgaris Bory 
Genus: Meridion C.Agardh M. circulare (Greville) C.Agardh

Order: Fragilariales P.C.Silva

Family: Fragilariaceae Kützing

Genus: Fragilaria Lyngbye

F. crotonensis Kitton

Genus: Synedra Ehrenberg

S. ostenfeldii (Willi Krieger) Cleve-Euler ex Stalberg

S. ulna (Nitzsch) Ehrenberg

Order: Thalassionematales Round

Family: Thalassionemataceae Round

Genus: Thalassionema Grunow ex Mereschkowsky

T. nitzschioides (Grunow) Mereschkowsky

Subclass: Eunotiophycidae D.G.Mann

Order: Eunotiales P.C.Silva

Family: Eunotiaceae Kützing

Genus: Eunotia Ehrenberg

E. arcus Ehrenberg

E. rhomboidea Hustedt

Class: Mediophyceae Medlin \& Kaczmarska

Subclass: Thalassiosirophycidae Round \& R.M.Crawford

Order: Stephanodiscales Nikolaev \& Harwood

Family: Stephanodiscaceae I.V.Makarova

Genus: Cyclotella (Kützing) Brébisson

C. comta Kützing

C. meneghiniana Kützing

C. striata (Kützing) Grunow

Order: Thalassiosirales Glezer \& Makarova

Family: Skeletonemataceae Lebour

Genus: Skeletonema Greville

S. costatum (Greville) Cleve

Class: Coscinodiscophyceae Round \& R.M.Crawford

Order: Rhizosoleniales P.C.Silva

Family: Rhizosoleniaceae De Toni

Genus: Rhizosolenia Brightwell

$R$. setigera Brightwell

Subclass: Coscinodiscophycidae Round \& R.M.Crawford

Order: Coscinodiscales Round \& R.M.Crawford

Family: Coscinodiscaceae Kützing

Genus: Coscinodiscus Ehrenberg

C. centralis Ehrenberg

C. curvatulus Grunow

C. granii L.F.Gough

C. radiatus Ehrenberg

Subclass: Melosirophycidae E.J.Cox

Order: Melosirales R.M.Crawford 
Family: Melosiraceae Kützing

Genus: Melosira C.Agardh

M. nummuloides C.Agardh

M. varians C.Agardh

Phylum: Miozoa Cavalier-Smith

Class: Dinophyceae F.E.Fritsch

Order: Amphidiniales Moestrup \& Calado

Family: Amphidiniaceae Moestrup \& Calado

Genus: Amphidinium Claperède \& Lachmann

A. mootonorum Shauna Murray \& D.J.Patterson

A. scissum Koifoid \& Swezy

Order: Gymnodiniales Apstein

Family: Gymnodiniaceae Lankester

Genus: Gymnodinium F.Stein

G. catenatum H.W.Graham

Genus: Akashiwo G.Hansen \& Moestrup

A. sanguinea (K.Hirasaka) Gert Hansen \& Moestrup

Family: Gyrodiniaceae Moestrup \& Calado

Genus: Gyrodinium Kofoid \& Swezy

G. instriatum Freudenthal \& J.J.Lee

Family: Kareniaceae Bergholtz, Daugbjerg, Moestrup \& Fernández-Tejedor

Genus: Karenia Gert Hansen \& Moestrup

K. brevis (C.C.Davis) Gert Hansen \& Moestrup

Family: Ptychodiscaceae (Schütt) Lemmermann

Genus: Ptychodiscus Stein

P. noctiluca Stein

Order: Peridiniales Haeckel

Family: Peridiniaceae Ehrenberg

Genus: Peridinium Ehrenberg

$P$. cinctum (O.F.Müller) Ehrenberg

Family: Podolampadaceae Lindemann

Genus: Podolampas F.Stein

$P$. palmipes Stein

P. spinifera Okamura

Order: Prorocentrales Lemmermann

Family: Prorocentraceae F.Stein

Genus: Prorocentrum Ehrenberg

P. cordatum (Ostenfeld) J.D.Dodge

$P$. gracile F.Schütt

$P$. hoffmannianum M.A.Faust

P. lima (Ehrenberg) F.Stein

$P$. mexicanum Osorio-Tafall

P. micans Ehrenberg

Phylum: Ochrophyta Cavalier-Smith

Class: Dictyochophyceae P.C.Silva

Order: Dictyochales Haeckel 
Family: Dictyochaceae Lemmermann

Genus: Dictyocha Ehrenberg

D. fibula Ehrenberg

Class: Eustigmatophyceae D.J.Hibberd \& Leedale

Order: Goniochloridales

Family: Goniochloridaceae

Genus: Tetraëdriella Pascher

T. limbata Pascher

Kingdom: Plantae Haeckel

Phylum: Chlorophyta Reichenbach

Class: Trebouxiophyceae Friedl

Order: Chlorellales Bold \& M.J.Wynne

Family: Chlorellaceae Brunnthaler

Genus: Actinastrum Lagerheim

A. hantzschii Lagerheim

Genus: Chlorella Beyerinck [Beijerinck]

C. vulgaris Beyerinck [Beijerinck]

Order: Trebouxiophyceae ordo incertae sedis

Family: Trebouxiophyceae incertae sedis

Genus: Crucigenia Morren

C. quadrata Morren

C. tetrapedia (Kirchner) Kuntze

Class: Chlorophyceae Wille

Order: Chlamydomonadales F.E.Fritsch

Family: Chlamydomonadaceae F.Stein

Genus: Chlamydomonas Ehrenberg

C. reinhardtii P.A.Dangeard

Family: Chlorococcaceae Blackman \& Tansley

Genus: Chlorococcum Meneghini

C. humicola (Nägeli) Rabenhorst

C. hypnosporum Starr

Family: Volvocaceae Ehrenberg

Genus: Eudorina Ehrenberg

E. elegans Ehrenberg

Genus: Pandorina Bory

P. morum (O.F.Müller) Bory

Family: Tetrasporaceae Wittrock

Genus: Tetraspora Link ex Desvaux

T. cylindrica (Wahlenberg) C.Agardh

Order: Sphaeropleales Luerssen

Family: Hydrodictyaceae Dumortier

Genus: Pediastrum Meyen

$P$. boryanum (Turpin) Meneghini

P. tetras (Ehrenberg) Ralfs

Family: Scenedesmaceae Oltmanns

Genus: Scenedesmus Meyen 
S. acuminatus (Lagerheim) Chodat

S. acutus Meyen

S. dimorphus (Turpin) Kützing

S. obliquus (Turpin) Kützing

S. quadricauda (Turpin) Brébisson in Brébisson \& Godey

Phylum: Charophyta Migula

Class: Zygnematophyceae Round ex Guiry

Subclass: Zygnematophycidae Melkonian, Gontcharov \& Marin

Order: Desmidiales C.E.Bessey

Family: Closteriaceae Bessey

Genus: Closterium Nitzsch ex Ralfs

C. acutum Brébisson

C. juncidum Ralfs

Family: Desmidiaceae Ralfs

Genus: Cosmarium Corda ex Ralfs

C. botrytis Meneghini ex Ralfs

C. nymannianum Grunow

C. phaseolus Brébisson ex Ralfs

Kingdom: Protozoa R.Owen

Phylum: Euglenozoa Cavalier-Smith

Class: Euglenophyceae Schoenichen

Subclass: Euglenophycidae Busse \& Preisfeld

Order: Euglenida F.Stein

Family: Euglenidae Dujardin

Genus: Euglena Ehrenberg

E. viridis (O.F.Müller) Ehrenberg

Family: Phacidae J.I.Kim, Triemer \& W. Shin

Genus: Phacus Dujardin

$P$. acuminatus Stokes

$P$. brevicaudata (G.A.Klebs) Lemmermann

P. longicauda (Ehrenberg) Dujardin

P. pleuronectes (O.F.Müller) Nitzsch ex Dujardin

\section{DISCUSSION}

From the previous studies conducted on the phytoplankton of the lake, we displayed the results of the studies that gave a list of the recorded species. Khalil (1990) investigated the plankton and primary productivity at 10 sites in Lake Manzala during June 1985-June 1986. He identified the phytoplankton at the generic level and recorded 24 genus, of them 10 belong to diatoms, 12 Chlorophyta and 2 Cyanophyta. El-Naggar et al. (1997) studied the effect of treated sewage on the quality of water and phytoplankton populations of Lake Manzala. They identified 157 species of phytoplankton, of them; 59 Chlorophyta, 37 Bacillariophyta, 30 Cyanophyta, 28 Euglenophyta, one Pyrrhophyta and two Cryptophyta. They stated that the phytoplankton 
standing crop was mainly due to the contribution of Bacillariophyta whereas the species composition is dependent mainly on Chlorophyta.

El-Sherif and Gharib (2001) studied species composition and diversity cycle of the phytoplankton community in Lake Manzala during the period from May 1992 to April 1993 at 11 sites. They recorded 141 phytoplankton species comprising 64 diatoms, 42 green algae, 24 blue-green algae, 5 dinofagellates and 6 Euglenophyceae. They reported that diatoms were the most important algae during the winter and spring. Chlorophyta were mainly observed during autumn, while Cyanophyta preferred summer. Fathi et al. (2001) collected phytoplankton seasonally from 10 sites in the lake during 1998 and identified 33 species. Of them; 12 Chlorophyceae, 10 Bacillariophyceae, 7 Cyanophyceae, 2 Euglenophyceae, one Cryptophyta and one Dinophyceae. Salah EI Din (2005) identified 57 phytoplankton species from Lake Manzala based on seasonal samples during 2003-2004 from 10 sites covered the whole lake. She found that Chlorophyta and Bacillariophyta were represented by 18 species each $(31.58 \%$ of the total phytoplankton each), 14 species belong to Cyanophyta (24.56\%), 6 species to Dinophyta (10.53\%) and only 1 species to Euglenophyta $(1.75 \%)$. In her study on the potential effect of Lake Manzala on the Suez Canal phytoplankton, Madkour (2007a) collected seasonal samples from two sites in the Lake Manzala, one at the northeastern part of the lake and the other site in El-Qabouty Canal. She authenticated 192 species belong to 8 groups; Bacillariophyta (90), Dinophyta (54), Chlorophyta (20), Cyanophyta (17), Euglenophyta (5), Charophyta (3), Cryptophyta (2), and Dictyophyceae (1).

The number of the recorded phytoplankton in the present study was compared with those recorded by previous studies and represented in Table (2). It can be observed from Table (2) that the phytoplankton community in Lake Manzala belonged to many taxonomic groups of phytoplankton (5-8), except in the study by Khalil (1990), belonged to three groups. Bacillariophyta and Chlorophyta represented the most important groups in terms of the number of species, giving collectively the percentage range of $>60 \%-75 \%$ in all studies, except that by Khalil (1990) where they represented about $90 \%$ of the community. The two groups alternated between the first and second orders except in the study by Madkour (2007a), when the Bacillariophyta kept its first order but Dinophlagelata came in the second order and Chlorophyta scored the third order. On the other hand, the percentage of Cyanophyta ranged between 2-30\%, occupying the third order in all the previous studies except in the study by Madkour (2007a) and in the present study, they arranged in the fourth order. This contradiction is not due to change in the lake trophic status but is mainly contributed to the nature of sampling sites. Whereas, one of sites in the present study and in the study by Madkour (2007a) positioned in the canal connects the lake with the Suez Canal (El-Qabouty Canal). It seems that the influence of Lake Manzala water diminishes through El-Qabouty canal and the effect of water exchange with the Suez Canal is pronounced. Other groups 
showed terminal importance in terms of number of species and represented by few species.

The composition of phytoplankton community in Lake Manzala is greatly influenced by the relatively high inflows of both freshwater and nutrients into Lake Manzala, producing a phytoplankton community dominated by Chlorophyta, and Cyanophyta which had fresh and brackish water affinity. In addition, receiving seasonal back flows of seawater from Mediterranean Sea and Suez Canal at sites I and IV, respectively enhanced the Bacillariophyta and Dinoflagelata to be more diversified, especially during the summer period (Madkour, 2005; Madkour et al., 2007b). The dominance of Bacillariophyta in terms of the number of species cauld be attributed to their tolerance to a wide range of salinity (Madkour, 2007b).

Table 2: Phytoplankton species composition recorded in the Lake Manzala by the previous studies and the present study.

\begin{tabular}{|c|c|c|c|c|c|c|c|}
\hline & $\begin{array}{c}\text { Khalil, } \\
1990\end{array}$ & $\begin{array}{l}\text { El-Naggar } \\
\text { et al., 1997 }\end{array}$ & $\begin{array}{l}\text { El-Sherif and } \\
\text { Gharib, 2001 }\end{array}$ & $\begin{array}{l}\text { Fathi et } \\
\text { al., 2001 } \\
\end{array}$ & $\begin{array}{c}\text { Salah El } \\
\text { Din, 2005 } \\
\end{array}$ & \begin{tabular}{|c|} 
Madkour, \\
2007a
\end{tabular} & $\begin{array}{c}\begin{array}{c}\text { Present } \\
\text { study }\end{array} \\
\text {. }\end{array}$ \\
\hline Bacillariophyta & $\begin{array}{c}10 \\
(42 \%)\end{array}$ & $37(23.3 \%)$ & $\begin{array}{c}64 \\
(45 \%)\end{array}$ & $\begin{array}{c}10 \\
(30.4 \%)\end{array}$ & $\begin{array}{c}18 \\
(31.6 \%)\end{array}$ & $\begin{array}{c}90 \\
(46.9 \%)\end{array}$ & $\begin{array}{c}51 \\
(46.8 \%)\end{array}$ \\
\hline Chlorophyta & $\begin{array}{c}12 \\
(50 \%)\end{array}$ & $59(37.3 \%)$ & $\begin{array}{c}42 \\
(30 \%)\end{array}$ & $\begin{array}{c}12 \\
(36.4 \%)\end{array}$ & $\begin{array}{c}18 \\
(31.6 \%)\end{array}$ & $\begin{array}{c}20 \\
(10.4 \%)\end{array}$ & $\begin{array}{c}17 \\
(15.6 \%)\end{array}$ \\
\hline Dinoflagellata & & $\begin{array}{c}1 \\
(0.6 \%) \\
\end{array}$ & $\begin{array}{c}5 \\
(3.5 \%) \\
\end{array}$ & $1(3 \%)$ & $\begin{array}{c}6 \\
(10.5 \%) \\
\end{array}$ & $\begin{array}{c}54 \\
(28.1 \%) \\
\end{array}$ & $\begin{array}{c}16 \\
(14.7 \%) \\
\end{array}$ \\
\hline Cyanobacteria & $\begin{array}{c}2 \\
(8 \%)\end{array}$ & $\begin{array}{c}30 \\
(19 \%)\end{array}$ & $\begin{array}{c}24 \\
(17 \%)\end{array}$ & $\begin{array}{c}7 \\
(21.2 \%)\end{array}$ & $\begin{array}{c}14 \\
(24.6 \%)\end{array}$ & $\begin{array}{c}17 \\
(8.9 \%)\end{array}$ & $\begin{array}{c}13 \\
(11.9 \%)\end{array}$ \\
\hline Euglenozoa & & $28(18.6 \%)$ & $\begin{array}{c}6 \\
(4.5 \%) \\
\end{array}$ & $\begin{array}{c}2 \\
(6 \%)\end{array}$ & $\begin{array}{c}1 \\
(1.7 \%)\end{array}$ & $\begin{array}{c}5 \\
(2.7 \%) \\
\end{array}$ & $\begin{array}{c}5 \\
(4.6 \%) \\
\end{array}$ \\
\hline Charophyta & & $\begin{array}{c}2 \\
(1.3 \%)\end{array}$ & & & & $\begin{array}{c}3 \\
(1.5 \%)\end{array}$ & $\begin{array}{c}5 \\
(4.6 \%)\end{array}$ \\
\hline Cryptophyta & & & & $\begin{array}{c}1 \\
(3 \%) \\
\end{array}$ & & $\begin{array}{c}2 \\
(1 \%)\end{array}$ & \\
\hline Dictyochophyceae & & & & & & $\begin{array}{c}1 \\
(0.5 \%) \\
\end{array}$ & $\begin{array}{c}2 \\
(1.8 \%) \\
\end{array}$ \\
\hline Total & 24 & 157 & 141 & 33 & 57 & 192 & 109 \\
\hline
\end{tabular}

\section{REFERENCES}

Aamer, M.A. (1999). Exchange of water and zooplankton organisms between Lake Manzalah and Mediterranean Sea through Boughaz El-Gamil. M.Sc. thesis, Fac. Sci., Suez Canal Univ., Egypt, 344 pp.

Abd El-Karim, M.S. (2008). Monthly variations of phytoplankton communities in Lake Manzala. Global Vet., 2(6):343-350.

Abd El-Monem, A.M. and Kanswa, A.H. (2001). Some biotic and abiotic variables 
controlling primary productivity in hypertrophic lake (Lake Qarun-Egypt). Egypt. J. Aquat. Biol. Fish., 5(3):1-16.

Abdel-Moati, M.R. (1985). Studies on the chemistry of Lake Manzala water, Egypt. Ph.D. Thesis, Department of Oceanography, University of Alexandria.

Botes, L. (2003). Phytoplankton identification catalogue. Saldanha Bay, South Africa. GloBallast monograph no (7).

Bourrelly, P. (1980). Les algues d'eau douce Intitiation a la systematique Tomo II: Les algues javunes et brunes Chrysophyces, Pheophyces, Xanyhophyces et Diatomees. II Place Saint Michel Paris. (6e).

Delgado, M. (1990). Phytoplankton distribution along the Spanish coast of the Alboran Sea. Sciecias del Mar. Barcelona, 54: 169-178.

Deyab, M.A.;Abu Ahmed, S.E. and Ward, F.M.E. (2019). Comparative studies of phytoplankton compositions as a response of water quality at North El-Manzala Lake, Egypt. International Journal of Environmental Science and Technology, 16: 8557-8572.

El-Asmar, H.M. and Hereher, M.E. (2015). Change detection of the coastal zone east of the Nile Delta using remote sensing. Environ. Earth Sci., 62(4): 769-777.

El-Bokhty, E.E. (1996). Distribution of bottom fauna in the Lake Manzala in relation to prevailing environmental conditions. M.Sc. Thesis, Fac. Sci., Tanta Univ., Egypt. $124 \mathrm{pp}$.

Elmorsi R.R., Hamed, M.A. and Abou-El-Sherbini, K.S. (2017). Physicochemical properties of Manzala Lake, Egypt. Egypt. J. Chem., 60(4):519-535.

El-Naggar, M.E.; Shaaban-Dessouki, S.A.; Abdel-Hamid, M.I. and Aly, E.M. (1997). Effect of treated sewage on the water quality and phytoplankton populations of Lake Manzala (Egypt) with emphasis on biological assessment of water quality. New Microbiologica, 20: 253-276.

El-Sherif, Z.M. and Gharib, S. (2001). Spatial and temporal patterns of phytoplankton communities in Manzala Lagoon. Bulletin Institute Oceanography \& Fisheries, Alexandria, 27: 217-239.

Fathi, A.A.; Abdelzaher, H.M.A.; Flower, R.J.; Ramdani M. and Kraiem, M.M. (2001). Phytoplankton communities in North African wetland lakes: the CASSARINA Project. Aquatic Ecology, 35: 303-318.

Fayed, D.B. (2004). Aspects of Manzalah Lake pollution on Mugil Species. M.Sc. Thesis, Girls' College, Ain Shams University. 
Fouad, A.B. (1926). Report on the fisheries of Egypt for the year, 1925. Ministry of Finance, Egypt, Coast Gards and Fisheries Service. Cairo, Government Press.

Gab-Allah, M.M. (1990). Some ecological studies on phytoplankton in Lake Manzalah. Ph.D. thesis, Fac. Sci., Suez Canal Univ., Egypt.

Hendey, N.I. (1946). An introductory account of the smaller algae of Biritish coastal waters. Part V: Bacillariopycea (Diatoms). Her Majesty's Stationery Office, London.

Hereher, M.H. (2014). The Lake Manzala of Egypt: an ambiguous future. Environ. Earth Sci., 72: 1801-1809.

Ibrahim, E.A. (1989). Studies on phytoplankton in some polluted areas of Lake Manzala. Bulletin of the National Institute of Oceanography and Fisheries A.R.E., 15(1):1-19.

Ismail, A. and Hettiarachchi, H. (2017). Environmental damage caused by wastewater discharge into the Lake Manzala in Egypt. Am. J. Biosci. Bioeng., 5(6):141-150.

Khalil, M. (1990). Plankton and primary productivity of Lake Manzala, Egypt. Hydrobiologia, 196: 201-207.

Madkour, F.F. (2005). Spatial variability of the spring phytoplankton distribution in Port Said Coast (Egypt). Egyptian Journal of Phycology, 6: 57-71.

Madkour, F.F. (2007a). The potential impact of Lake Manzala on the phytoplankton and hydrographic characters of the Suez Canal, Egypt. Egyptian Journal of Aquatic Biology \& Fisheries, 11(2): 185-204.

Madkour, F.F. (2007b). Phytoplankton composition and population density as indicators of eutrophication in Lake Timsah, Suez Canal, Egypt. Egyptian Journal of Aquatic Biology \& Fisheries, 11(3): 507-525.

Madkour, F.F.; Dorgham, M.M. and Fahmy, M.A. (2007a). Short-term scale observations on phytoplankton in the Eastern Harbor of Alexandria, Egypt. Egyptian Journal of Aquatic Research, 33(1): 193-209.

Madkour, F.A., Dorgham, M.M., Hanafi, M.H. and Holligan, P.M. (2007b). Comprehensive hydrobiological observations on the Suez Canal. International Journal of Oceans and Oceanography, 2(1): 125-137.

Meininger, P.L. and Atta, G.A. (1992). Ornithological studies in Egyptian wetlands 1989/90. WIWO Report, fore report, Zeist /Middleburg.

Prescott, A.G.W. (1978). How to know the freshwater algae, (third edition), 293 pp. 
Ramdani, M.; Elkhiati, N.; Flower, R.J.; Thompson, J.R.; Chouba, L.; Kraiem, M.M.; Ayache, F. and Ahmed, M.H. (2009). Environmental influences on the qualitative and quantitative composition of phytoplankton and zooplankton in North African coastal lagoons. Hydrobiologia, 622:113-131.

Rashad, H.M. and Abdel-Azeem, A.M. (2010). Lake Manzala, Egypt: A bibliography. Assiut Univ. J. of Botany, 39(1): 253-289.

Riley, G.A. (1967). Phytoplankton of long Island Sound. Bull. Bingh. Oceagi. Cell., 19: 5-34.

Salah El-Din, R.A. (2005). Change in physico-chemical characters and its impact on phytoplankton structure of Lake Manzala, Egypt. Journal of Phycology, 6:111126.

Smolyakov, B.; Ryzhikh, A. and Romanov, R. (2010). The fate of $\mathrm{Cu}, \mathrm{Zn}$, and $\mathrm{Cd}$ in the initial stage of water system contamination: the effect of phytoplankton activity. J Hazard Mater 184(1-3):819-825. 